\title{
Susceptibility of different genotypes of rice to Sitophilus zeamais Motschulsky 1885 attack (Coleoptera: Curculionidae)
}

\author{
Tatiane Colares ${ }^{1}$, Rafael G. Dionello ${ }^{1}$ \& Lauri L. Radunz ${ }^{2}$ \\ ${ }^{1}$ Universidade Federal do Rio Grande do Sul/Faculdade de Agronomia/Departamento de Fitossanidade. Porto Alegre, RS. E-mail: tatianecolaresufrgs@gmail.com \\ (Corresponding author); rafdionello@hotmail.com \\ ${ }^{2}$ Universidade Federal da Fronteira Sul. Erechim, RS. E-mail: laurilr@gmail.com
}

\section{Key words:}

resistance

rice genotypes

storage

weevil

\begin{abstract}
A B S T R A C T
Rice (Oryza spp.), the most important cereal in the world, is grown and consumed in all continents. Brazil is among the top ten producing countries. Stored grains can be attacked by pests (rodents, insects, fungi and mites) that cause serious qualitative and quantitative losses. Because of these losses, one way to alleviate the problem caused by insects during rice storage is the use of resistant materials (grains). Thus, the aim of this study was to evaluate grains from nine different genotypes of rice, in order to identify the existence of materials less susceptible to the attack of Sitophilus zeamais, during 180 days of storage. The mean time of biological cycle (days), susceptibility index (IS) and the number of weevils emerged were evaluated. According to the results, grains of the genotypes IRGA 426 and Puita were the most susceptible and the genotypes BR-IRGA 409, IRGA 424, IRGA 425 and IRGA 427 were the least susceptible to the attack of Sitophilus zeamais.
\end{abstract}

Palavras-chave: resistência genótipos de arroz armazenamento gorgulho

\section{Suscetibilidade de diferentes genótipos de arroz ao ataque de Sitophilus zeamais Motschulsky 1885 (Coleoptera: Curculionidae)}

\footnotetext{
R E S U M O

O arroz (Oryza spp.) cereal de maior importância alimentar no mundo, é cultivado e consumido em todos os continentes. O Brasil está entre os dez principais países produtores. Os grãos armazenados podem ser atacados por pragas (roedores, insetos, fungos e ácaros) que causam sérias perdas qualitativas e quantitativas. Em função dessas perdas uma das formas de minimizar o problema ocasionado por insetos durante o armazenamento de arroz é com o uso de materiais (grãos) resistentes. Assim, o objetivo com este trabalho foi avaliar grãos oriundos de nove diferentes genótipos de arroz procurando-se identificar a existência de materiais menos suscetíveis ao ataque de Sitophilus zeamais, durante 180 dias de armazenamento. Foram avaliados o tempo médio do ciclo biológico (dias), o índice de suscetibilidade (IS) e o número de gorgulhos emergidos. Os resultados nos permitem concluir que grãos dos genótipos IRGA 426 e Puitá foram os mais suscetíveis e os dos genótipos BR-IRGA 409, IRGA 424, IRGA 425 e IRGA 427 são os menos suscetíveis ao ataque de Sitophilus zeamais.
} 


\section{INTRODUCTION}

Rice (Oryza spp. L.), the most important cereal in the world, is cultivated and consumed in all continents. It stands out for the production and cultivation area, and plays an important strategic role in both economic and social aspects. Approximately $90 \%$ of the all the rice in the world is cultivated and consumed in Asia. In this scenario, Latin America occupies the second position in production and the third in consumption (EMBRAPA, 2005; 2011).

According to CONAB (2014), Brazil is among the ten main rice producing countries, with national production of 12.7 million tons in the $2013 / 2014$ season. The state of Rio Grande do Sul is the main producing state, with $61 \%$ of this total. Along with the effort to increase production, it is also essential to improve not only the production process, but also the storing conditions, because in the storing phase, according to Lorini (2008) and IBGE (2012), the damages caused by the attack of pests to the grains may reach $10 \%$ of the total annual production in Brazil.

In general, grains are attacked by pests during the storage, especially insects and fungi, which cause irreversible losses, whether quantitative or qualitative. For Souza et al. (2012), such damages occur due to the reduction of grain weight, besides commercial devaluation, loss of nutritive value, germination power and contamination by mites and fungi. Additionally, there may be an increase in the number of grains with defects, color alteration or production of mycotoxins during the storage. According to Fontes et al. (2003), the damages caused in the field can be compensated by the recovery of the damaged plant or by the increase in the yield of non-attacked pants; however, the damages in stored grains are irreversible.

Because of these losses, the control of insects in storage systems in Brazil is performed using insecticides that, besides causing death of insects, avoid reinfestation, because they can remain in the grains for longer periods (Hagstrum \& Subramanyam, 2006). However, the capacity of the insects to notice chemical substances through sensorial processes may select populations resistant to these products, compromising a good management in pest control (Silva et al., 2014). Furthermore, this method has been questioned because of doubts regarding food safety, since the residues of these insecticides pose risks to animals and human beings and can contaminate the environment.

In order to reduce the high losses during storage, especially with respect to the attack of insects, one alternative to insecticides is the study of resistant genotypes (varieties). This type of management has a series of advantages compared with the use of chemical insecticides, such as: no increase in production costs, no risks to human and animal health, reduction in quantitative and qualitative losses, no pollution to the environment and compatibility with other control strategies, since it does not eliminate natural enemies and does not leave pesticide residues in the food (Mazzoneto \& Boiça Júnior, 1999).

Thus, this study aimed to evaluate the susceptibility of rice grains from nine genotypes to infestation and damage of Sitophilus zeamais, during 180 days of storage.

\section{Material and Methods}

The experiment started in June 2012 and was installed at the Grain Postharvest Laboratory of the Federal University of Rio Grande do Sul, in the municipality of Porto AlegreRS, Brazil. Rice (Oryza sativa L.) grains came from farmers of the state of Rio Grande do Sul, provided by the IRGA (Rice Institute of Rio Grande do Sul). The genotypes were selected among the most cultivated varieties in Rio Grande do Sul and the grains came from the 2011/2012 season. The nine studied rice genotypes were: BR-IRGA 409; IRGA 417; IRGA 424; IRGA 425; IRGA 426; IRGA 427; Puitá Inta CL; Avaxi CL and Olimar.

The insects used in the experiment were identified at the Federal University of Viçosa (UFV) through the study of their DNA (Corrêa et al., 2012) and belonged to the species $S$. zeamais. These insects were raised in chambers with controlled temperature and $\left(25 \pm 2{ }^{\circ} \mathrm{C}\right)$ and relative humidity $(60 \pm 5 \%)$, and the food substrate was rice grains from genotype IRGA416 , which was not evaluated in the present study.

Prior to the experiment, the grains were maintained in a freezer at temperature of $-20{ }^{\circ} \mathrm{C}$ for 10 days, for disinfection and in order to avoid the emergence of eggs from the field.

To verify the susceptibility of rice grains from different genotypes to the attack of insects, these grains were subjected to the no-choice test, because it allows verifying the influence of the genotypes on the biology of the insect.

The no-choice test was performed as follows: $100 \mathrm{~g}$ samples of each rice genotype were placed in $300 \mathrm{~mL}$ transparent plastic containers, along with 30 unsexed adult insects of S. zeamais, (Guzzo et al., 2002; Herrmann et al., 2009; Marsaro Júnior \& Vilarrinho, 2011; Vásquez-Castro et al., 2012; Sousa et al., 2013) and covered with voile fabric to prevent the escape of insects. No disinfection was performed in the control treatment, which consisted of only rice grains. All the containers were maintained for seven days under controlled temperature of $25^{\circ} \mathrm{C}$, to allow the oviposition of insects on the grains. Then, the insects were removed and, after 15 days, daily observations started in order to evaluate the emergence. Emerged insects were removed from the containers and counted until emergence stopped.

After this procedure, development cycle duration (egg to adult emergence) and the number of emerged insects were calculated and the index of susceptibility (IS) was determined according to Dobie (1977), which is based on the analysis of the number of daily emerged weevils, along the mean development time, after infestation of the genotypes with $S$. zeamais, according to Eqs. 1 and 2:

$$
\begin{gathered}
\mathrm{IS}=\frac{\ln \sum \mathrm{x}}{\mathrm{T}} \times 100 \\
\mathrm{~T}=\frac{\sum(\mathrm{x} \cdot \mathrm{y})}{\sum \mathrm{x}}
\end{gathered}
$$

where:

IS - index of susceptibility;

ln - natural logarithm; 
$\Sigma \mathrm{x}$ - sum of the number of emerged weevils for each hybrid;

$\mathrm{T}$ - mean time for weevils to complete biological cycle;

$\mathrm{X}$ - number of weevils emerged daily; and

$\mathrm{Y}$ - number of days from infestation to emergence.

Additionally, the potential of grain losses (PL) was evaluated through the observation of presence/absence of fissures between the palea and the lemma, and estimated using 250 grains from each rice genotype, according to Ribeiro et al. (2012), through Eq. 3:

$$
\mathrm{PL} \%=\frac{\mathrm{NGF}}{\mathrm{N}} \times 100
$$

where:

NGF - number of grains with fissures in the sample; and $\mathrm{N}$ - sample size.

The experiment was set in a completely randomized design, with nine treatments (rice genotypes) and four replicates. The obtained data were initially subjected to analysis of variance (F test) and, when significant, to Tukey test ( $\mathrm{p} \leq 0.05)$ using the statistical program SAS.

The genotypes were also subjected to hierarchical cluster analysis, based on the nearest neighbor through the Euclidean distance matrix and graphically arranged in a dendrogram using the program SPSS $20^{\circ}$.

\section{Results AND Discussion}

The data referring to the mean values of biological cycle (days), index of susceptibility (IS) and number of weevils emerged, obtained in the no-choice test, are described in Table 1.

According to the observed results (Table 1), the genotypes IRGA 425, Puitá, Avaxi, Olimar and IRGA 427 promoted the longest biological cycle for the insects. On the other hand, the shortest biological cycle was promoted by the genotypes BR IRGA 409, IRGA 424, IRGA 426 and IRGA 417.

The longer the biological cycle of these insects, the less susceptible the genotypes are and vice versa (Herrmann et al., 2009). Guzzo et al. (2002), evaluating the susceptibility of

Table 1. Mean values of biological cycle (BC), index of susceptibility (IS) and number of weevils emerged (NWE) in nine rice genotypes during 180 days of storage

\begin{tabular}{lccc}
\hline \multicolumn{1}{c}{ Genotype } & $\begin{array}{c}\text { BC } \\
\text { (days) }\end{array}$ & \multicolumn{1}{c}{ IS } & NWE \\
IRGA 425 & $35.35 \mathrm{a}$ & $4.07 \mathrm{f}$ & $4.50 \mathrm{e}$ \\
Puitá & $34.55 \mathrm{a}$ & $11.54 \mathrm{ab}$ & $54.53 \mathrm{a}$ \\
Avaxi & $34.34 \mathrm{a}$ & $9.13 \mathrm{~cd}$ & $24.33 \mathrm{~cd}$ \\
Olimar & $33.31 \mathrm{ab}$ & $10.10 \mathrm{abc}$ & $31.00 \mathrm{bc}$ \\
IRGA 427 & $32.81 \mathrm{abc}$ & $6.18 \mathrm{e}$ & $6.25 \mathrm{e}$ \\
BR-IRGA 409 & $31.21 \mathrm{bcd}$ & $7.51 \mathrm{de}$ & $9.50 \mathrm{e}$ \\
\hline IRGA 424 & $30.85 \mathrm{bcd}$ & $7.17 \mathrm{e}$ & $9.00 \mathrm{e}$ \\
IRGA 426 & $33.43 \mathrm{~cd}$ & $11.61 \mathrm{a}$ & $33.50 \mathrm{~b}$ \\
\hline IRGA 417 & $29.76 \mathrm{~d}$ & $9.81 \mathrm{bc}$ & $21.50 \mathrm{~d}$ \\
\hline
\end{tabular}

${ }^{*}$ Means followed by the same lowercase letter in the column do not differ statistically by Tukey test $(\mathrm{p} \leq 0.05) ; \mathrm{CV}: \mathrm{BC}=3.28 \%$; IS $=8.57 \%$ and NWE $=12.86 \%$ corn grains from two varieties to $S$. zeamais, observed variation of 43.3 to 49.9 days in the biological cycle of this species. Marsaro Júnior et al. (2008) observed that the biological cycle of S. zeamais ranged from 39.6 to 45.5 days, in different corn varieties, indicating that there are differences between distinct types of grains, as well as between genotypes, which was evidenced in the present study with rice, for the different genotypes studied. In the present study, the least susceptible genotypes regarding the parameter of biological cycle were IRGA 425, Puitá, Avaxi, Olimar and IRGA 427. According to Lorini (2008), the cycle from egg to adult emergence, for Sitophilus zeamais, is approximately of 34 days, similar to the results found in the present study.

It is also possible to observe (Table 1 ) that the genotype IRGA 426 showed the highest mean for the index of susceptibility (IS), but did not differ from Puitá and Olimar. On the other hand, the genotype IRGA 425 showed the lowest IS and differed statistically from all the others. According to Herrmann et al. (2009), the higher the index of susceptibility, the more susceptible the varieties can be considered. According to Gomes \& Santos (1993), the index of susceptibility (IS) is correlated with important genetic factors of susceptibility, such as grain weight loss, number of F1 descendants, grain hardness and insect reproduction rate. Therefore, the genotype IRGA 425 was less susceptible to this pest, while IRGA 426, Puitá and Olimar were more susceptible. The variation in the results obtained in the present study ( 4.07 to 11.61 ) is similar to variations found by other authors, such as Santos et al. (2006), who reported variation from 7.58 to 10.73 , Marsaro Júnior et al. (2008) from 8.45 to 10.23, Herrmann et al. (2009) from 1.7 to 7.0 and Mikami et al. (2012) from 2.8 to 4.6, all of them for the same pest, but in corn grains. However, still according to Table 1, regarding the number of emerged weevils, the highest number of emerged insects of the species S. zeamais occurred in the genotype Puitá, while the lowest number occurred in the genotypes BR-IRGA409, IRGA 424, IRGA 427 and IRGA 425. The total variation of emerged insects in the present study was from 4.5 to 54.53 , indicating the existence of important differences between the evaluated rice genotypes.

According to Guzzo et al. (2002), besides the previously mentioned factors, one of the most important indicators of antibiosis is larval death, which can be evidenced by the low number of emerged adults, as in the case of BR-IRGA 409, IRGA 424, IRGA 427 and IRGA 425, which showed the lowest values of emerged insects. The same authors observed variation of $12 \pm 5.87$ to $49 \pm 7.62$ emerged insects in six corn genotypes. Boiça Júnior et al. (1997), evaluating 11 corn genotypes, observed variation of $5.00 \pm 1.88$ to $24.2 \pm 3.28$ emerged insects, while Herrmann et al. (2009) reported variation of 3.0 to 36.3 emerged insects in 10 corn varieties and Mikami et al. (2012) found variation of $23 \pm 8$ and $84.6 \pm 7$ emerged insects in 13 corn genotypes. All of these studies used the species S. zeamais.

According to Marsaro Júnior et al. (2008), there is a strong relationship between insect cycle and the number of emerged adult insects. Thus, it is assumed that the product becomes more susceptible as the number of emerged insects increase and emergence time decreases, and less susceptible as the cycle increases and the number of insects decreases. 
The genotype Puitá showed higher number of emerged weevils and index of susceptibility, but with longer biological cycle. The genotype IRGA 426, besides having lower number of days for the insect to complete its biological cycle, had the highest index of susceptibility and showed the second highest number of emerged insects. These two genotypes showed the highest susceptibility for all the parameters evaluated so far.

The genotype IRGA 426 showed the highest potential of loss and number of grains with fissures (Table 2), statistically differing from the others.

These values corroborate the previously shown results. The genotype IRGA 426 is one of those with highest susceptibility to the attack of insects and the genotypes Olimar, IRGA 425 and IRGA 427 are the least susceptible to $S$. zeamais. The index of susceptibility is related to the number of grains with fissures, since the insects attacking rice grains lay eggs on damaged grains or grains with fissures between the palea and the lemma, consequently causing greater potential of loss.

Ribeiro et al. (2012), in a study with 14 rice genotypes, observed variation in the percentage of losses of 1.1 to $44.75 \%$, showing that this is also an important parameter to evaluate the susceptibility of rice grains to storage pest insects.

Link \& Rosseto (1972) reported that the susceptibility of genotypes can be defined through the evaluation of grains with respect to the existence of fissures between the palea and the lemma.

According to the analysis of variance by $\mathrm{F}$ test, the five studied variables showed significant effect. The dendrogram resulting from the cluster analysis of these variables is shown in Figure 1.

As shown in Figure 1, from the joint analysis of the 5 responses (cycle, IS, emerged weevils, PL and NGF), considering the Euclidean distance of 6 , it can be inferred that the grains of the genotypes BR-IRGA 409, IRGA 424, IRGA 425 and IRGA 427 were the least susceptible to S. zeamais. Likewise, the genotypes Avaxi, Olimar and IRGA 417 have intermediate susceptibility, while IRGA 426 and Puitá were the most susceptible to $S$. zemais, i.e., they have higher possibility of losses caused by this pest.

According to Ribeiro et al. (2012), the opening in the husk of the grains allows the infestation of S. oryzae and S. zeamais in rice varieties and this characteristic is undesirable for the selection of genotypes with resistance to pests of stored grains. Therefore, in the present study and in general, the genotypes with lower number of grains with fissures were the most

Table 2. Mean values of potential of loss (PL\%) and number of grains with fissures (NGF) in nine rice genotypes, during 180 days of storage

\begin{tabular}{lll}
\hline Genotypes & PL (\%) & NGF \\
IRGA 426 & $8.00 \mathrm{a}$ & $20.00 \mathrm{a}$ \\
IRGA 417 & $5.20 \mathrm{~b}$ & $13.00 \mathrm{~b}$ \\
Puitá & $4.66 \mathrm{bc}$ & $11.66 \mathrm{bc}$ \\
BR-IRGA 409 & $3.73 \mathrm{~cd}$ & $9.33 \mathrm{~cd}$ \\
IRGA 424 & $3.60 \mathrm{~cd}$ & $9.00 \mathrm{~cd}$ \\
Olimar & $3.20 \mathrm{de}$ & $8.00 \mathrm{de}$ \\
IRGA 425 & $2.20 \mathrm{ef}$ & 5.50 ef \\
IRGA 427 & $2.20 \mathrm{ef}$ & 5.50 ef \\
Avaxi & $2.00 \mathrm{f}$ & $5.00 \mathrm{f}$ \\
\hline *Means followed by the same lowercase letter in the column do not differ statistically by
\end{tabular}

*Means followed by the same lowercase letter in the column do not differ statistically by Tukey test $(p \leq 0.05) ; C V: P L=10.43 \%$ and $N G F=10.44 \%$

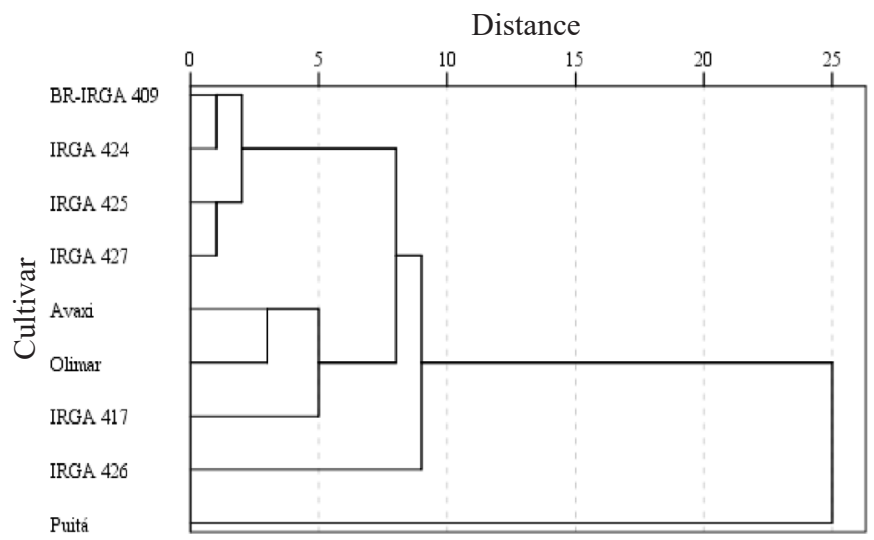

Figure 1. Hierarchical cluster dendrogram from the Euclidean distance for nine rice genotypes, during 180 days of storage, regarding the susceptibility to the attack of $S$. zeamais

resistant to the attack of $S$. zeamais. However, other factors may be involved, such as grains hardness and chemical composition. According to Marsaro Júnior et al. (2005), the high lipid content and the presence of amylase inhibitors in corn grains prolong the biological cycle of corn weevil and, consequently, increase the resistance of the genotypes, factors that can also contribute to the resistance of rice cultivars. However, these authors observed that the contents of proteins and carbohydrates in the grains do not influence the resistance of corn grains to the attack of this insect.

The results obtained in this study corroborate those reported by Fontes et al. (2003), Sousa et al. (2010), Vasconcellos et al. (2013) and Silva et al. (2014), who also observed difference in susceptibility to $S$. zeamais between different rice genotypes. Thus, researches in this field are of great importance, because there are not many studies evaluating the resistance of rice grains to the attack of $S$. zeamais. These results can significantly contribute to the reduction in the use of pesticides in the control of storage pests, allowing the supply of grains free from the residues of these products, a requirement from the consumers that has greatly increased in the last years.

\section{Conclusions}

1. Grains of the genotypes IRGA-426 and Puita are the most susceptible to the attack of Sitophilus zeamais.

2. Grains of the genotypes BR-IRGA 409, IRGA 424, IRGA 425 and IRGA 427 are the least susceptible to the attack of Sitophilus zeamais.

\section{Literature Cited}

Boiça Júnior, A. L.; Lara, F. M.; Guidi, F. P. Suscetibilidade de genótipos de milho ao ataque de Sitophilus zeamais (Mots.) (Coleoptera: Curculionidae). Anais Sociedade Entomológica do Brasil, v.26, p.481-485, 1997. http://dx.doi.org/10.1590/S030180591997000300010

CONAB - Companhia Nacional de Abastecimento. Acompanhamento da safra brasileira: Grãos: Safra 2013/2014. 2014. http://www. conab.gov.br/OlalaCMS/uploads/arquivos/14_03_12_08_41_24_ boletim_graos_marco_2014.pdf. 19 Set. 2014. 
Corrêa, A. S.; Oliveira, L. O. de; Braga, L. S.; Guedes, R. N. C. Distribution of the related weevil species Sitophilus oryzae and $S$. zeamais in Brazil. Insect Science, v. 20, p.1-8, 2012.

Dobie, $\mathrm{P}$. The contribution of the tropical stored products centre to the study of insect resistance in stored maize. Tropical Stored Products Information, v.34, p.7-22, 1977.

EMBRAPA - Empresa Brasileira de Pesquisa Agropecuária. 2005. (Sistemas de Produção, 3). <http://sistemasdeproducao.cnptia. embrapa.br/FontesHTML/Arroz/ArrozIrrigadoBrasil/cap16.htm>. 19 Dec. 2013.

EMBRAPA - Empresa Brasileira de Pesquisa Agropecuária, 2011. (Agência Embrapa de Informação Tecnológica). Arroz: Estatísticas de produção. <http://www.agencia.cnptia.embrapa.br/gestor/ arroz/arvore/CONT000fe7457q102wx5eo07qw4xezy8czjj.html>. 19 Dec. 2013.

Fontes, L. S.; Almeida Filho, A. J.; Arthur, V. Danos causados por Sitophilus oryzae (Linné, 1763) e Sitophilus zeamais Motschulsky, 1855 (coleoptera: curculionidae) em cultivares de arroz (Oryza sativa L.). Arquivos do Instituto Biológico, v.70, p.303-307, 2003.

Gomes, H. S.; Santos, J. P. Infestacion y dano del Sitophilus zeamais en diez genotipos de maiz. Revista Colombiana de Entomologia, Santafé de Bogotá, v.19, p.6-9, 1993.

Guzzo, E. C.; Alves, L. F. A.; Zanin, A.; Vendramin, J. D. Identificação de materiais de milho resistentes ao ataque de gorgulho Sitophilus zeamais (Mots., 1855) (Coleoptera: Curculionidae). Arquivo do Instituto Biológico, v.69, p.69-73, 2002.

Hagstrum, D.W.; Subramanyam, B. Fundamentals of stored-product entomology. St. Paul: AACC Internacional, 2006. 323p.

Herrmann, D. R.; Carvalho, M.; Zachow, F.; Scholz, F.; Rabbers, D.; Tsutsumi, C.; Zonin, W. Avaliação da resistência de cultivares de milho ao ataque de Sitophilus sp. em grãos armazenados. Revista Brasileira de Agroecologia, v.4, p.4290-4293, 2009.

IBGE - Instituto Brasileiro de Geografia e Estatística. Banco de dados Agregados. <http://www.sidra.ibge.gov.br/bda/agric/default. asp? $\mathrm{z}=\mathrm{t} \& \mathrm{o}=11 \& \mathrm{i}=\mathrm{P}>\mathrm{.} 23$ Jul. 2012.

Link. D.; Rosseto, C. J. Relações entre fissuras na casca do arroz infestadas de Sitotroga cerealella (Olivier, 1819) (Lepidoptera Gelechiidae). Revista Peruana de Entomologia, v.15, p.225-227, 1972.

Lorini, I. Manejo integrado de pragas de grãos de cereais armazenados. Passo Fundo: Embrapa Trigo, 2008.

Marsaro Júnior, A. L.; Lazzari, S. M. N.; Figueira, E. L. Z.; Hirooka, E. Y. Inibidores de amilase em híbridos de milho como fator de resistência a Sitophilus zeamais (Coleoptera: Curculionidae). Neotropical Entomology, p.443-450 2005. http://dx.doi. org/10.1590/s1519-566x2005000300013

Marsaro Júnior, A. L.; Vilarinho, A. A. Resistência de cultivares de feijão-caupi ao ataque de Callosobruchus maculatus (Coleoptera: Chrysomelidae: Bruchinae) em condições de armazenamento. Revista Acadêmica Ciência Animal, v.9, p.51-55, 2011.
Marsaro Júnior, A. L.; Vilarinho, A. A.; Paiva, W. R. S. C.; Barreto, H. C. S. Resistência de híbridos de milho ao ataque de Sitophilus zeamais Motschulsky (Coleoptera: Curculionidae) em condições de armazenamento. Revista Acadêmica, Ciência Animal, v.6, p.45-50, 2008.

Mazzoneto, F.; Boiça Júnior, A. L. Determinação dos tipos de resistência de genótipos de feijoeiro ao ataque de Zabrotes subfasciatus (Boh.) (Coleoptera: Bruchidae). Anais da Sociedade Entomológica do Brasil, v.28, p.307-311, 1999. http://dx.doi. org/10.1590/S0301-80591999000200014

Mikami, A. Y.; Carpentieri-Pípolo, V.; Ventura, M. U. Resistance of maize landraces to the maize weevil Sitophilus zeamais Motsch. (Coleoptera: Curculionidae). Neotropical Entomology, v.41, p.404-408, 2012. http://dx.doi.org/10.1007/s13744-012-0054-8

Ribeiro, C. S. N.; Martins, G. V.; Guimarães, J. F. R.; Silva, E. F. Suscetibilidade de genótipos de arroz a pragas de grãos armazenados. Revista Caatinga, v.25, p.183-187, 2012.

Santos, J. P.: Guimarães, P. E. O.; Waquil, J. M.; Foster, J. E. Relative index of susceptibility to the maize weevil, Sitophilus zeamais, among some qpm corn lines. Revista Brasileira de Milho e Sorgo, v.5, p.159-169, 2006. http://dx.doi.org/10.18512/1980-6477/rbms. v5n2p159-169

Silva, D. C.; Almeida, A. C. S.; Duarte, D. M.; Corrêa, F.; Freitas, M. M.; Lacerda, M. Barrigossi, C.; J. A. F.; Jesus, F. G. Resistência de variedades de arroz a Sitophilus zeamays (Coleoptera: Curculionidae). In: Congresso Brasileiro de Entomologia, 25, 2014, Goiana. Anais...Goiana: Embrapa Arroz e Feijão e a Universidade Federal de Goiás (UFG), 2014. CD-Rom

Sousa, A. H.; Faroni, L. R. A.; Andrade, G. S.; Freitas, R. S.; Pimentel, M. A. G. Bioatividade da terra de diatomácea para Sitophilus zeamais (Coleoptera: Curculionidae) em diferentes condições de aplicação. Revista Brasileira de Engenharia Agrícola e Ambiental, v.17, p.982-986, 2013. http://dx.doi.org/10.1590/ S1415-43662013000900011

Sousa, J. R.; Barrigossi, J. A. F.; Boiça Júnior, A. L.; Gonçalves, K. K. M.; Torres, E. R. S.; Mondego, J. M. Avaliação de resistência em variedades de arroz (Oryza sativa L.) ao ataque do Sitophilus oryzae Linnaeus, 1763 (Coleoptera: Curculionidae). Nucleus, v.7, p. 259-266, 2010. http://dx.doi.org/10.3738/1982.2278-314

Souza, A. R.; Silva, T. M.; Santos, J. F. L. Seleção e desenvolvimento de Sitophilus oryzae (Linné, 1763) em três substratos. Magistra, v.24, p.160-163,2012.

Vasconcellos, M. C. M.; Souza, D. C. T.; Botelho, F. B. S.; Furtini, I. V. Resistência de genótipos de arroz às pragas de armazenamento do gênero Sitophilus. In: Congresso Brasileiro de Melhoramento de Plantas, 7, 2013, Uberlândia. Anais...Uberlândia: Realizado pela Universidade Federal de Viçosa, p.2661-2664, 2013.

Vásquez-Castro, J. A.; de Baptista, G. C.; Gadanha Jr., C. D.; Trevizan, L. R. P. Insecticidal effect and residual action of fenitrothion and esfenvalerate on Sitophilus oryzae and S. zeamais (Coleoptera: Curculionidae) in stored maize and wheat, ISRN Agronomy, v.2012, p.1-11, 2012. http://dx.doi.org/10.5402/2012/158179 